\title{
VIZUÁLNA POCTA KU VZNIKU ČESKOSLOVENSKA A JEHO KRITICKÉ ČÍTANIE V SÚČASNOSTI - ALFONS MUCHA A JIŘÍ DAVID
}

\author{
EVA KAPSOVÁ
}

\begin{abstract}
KAPSOVÁ, Eva: A Visual Tribute to the Origin of Czechoslovakia and Its Contemporary Critical Readings Alfons Mucha and Jiř́ David, 2019, Vol. 1, Issue 1, pp. 95 - 102. DOI: 10.17846/CEV.2019.01.1.95-102.
\end{abstract}

\begin{abstract}
The monumental work The Slav Epic (1912 - 1926) by Alfons Mucha is one of most extraordinary artistic achievements not only in the history of Czechoslovak art, but also in the global context. This work was a commentary of, and part of, the political movement leading to the formation and "launch" of the Czechoslovak Republic in 1918. The premiere of entire cycle was held to mark the anniversary of the foundation of Czechoslovakia in 1928. This paper deals with the strategies used by Alfons Mucha in his reflections, but especially the new mythologization of the Slavic history in this work. The paper discusses his unique approach to evaluating the position of the Czech, Moravian or "Slovak" tribe in the process of constituting the "Czechoslovak nation" (?). Following Alfons Mucha, the paper also analyzes the reflection of this issue in the work Apotheosis (2015) by contemporary artist Jiří David.
\end{abstract}

KEYWORDS: Visual Mythology. Deconstruction of the Myth. Apotheosis. Alfons Mucha. Jiř́ David.

\section{ÚVOD D0 "OSMIČKOVÝCH“ ROKOV}

Osmičkovým vročeniam jubileí v našich dejinách nemožno prikladat nejaký mýtický či kultový význam, i ked’ sú akýmisi pomyslenými mantinelmi, ktoré s ohladom na ritualizovanú povahu kultúrnej pamäte tvoria príležitost' pre pozastavenie, úvahy, reflexiu a bilanciu minulého s prípadným výhladom do budúcnosti. „Osmičkové“ jubileá v dejinách našich národov chápeme ako príležitost̉ na reflexiu a prehodnotenie živého procesu permanentného u/pre/tvárania národnej identity. V našom príspevku sa budeme venovat’ v istom ohlade exkluzívnej téme - jubileu, ktoré je spojené s oslavou 10. výročia vzniku Československa na pôde umeleckej inštitúcie, ktorá v tom čase práve zahajovala svoju činnost'. Nepôjde nám o analýzu samotných osláv, ktoré v procese formovania národnej identity zohrávajú významnú úlohu (Hroch 2009, 203 - 258), ale o interpretáciu ich predmetu - maliarskeho cyklu, ktorý výnimočným spôsobom - ako ideová/ideologická figúra, vhodne zapadol do tejto slávnosti a následne sa stal predmetom odbornej i laickej reflexie a v súčasnosti aj predmetom umeleckej reinterpretácie $\mathrm{v}$ tvorbe významného súčasného českého výtvarného umelca Jiř́ho Davida.

\section{MUCHOVA EPOPEJA}

Na desiate výročie vzniku Československa 1. septembra 1928 bola otvorená výstava monumentálneho velkorozmerného cyklu malieb Alfonsa Muchu - Slovanská epopej. Slávnostné otvorenie výstavy a zároveň odovzdanie cyklu mestu Praha sa uskutočnilo za prítomnosti pražského starostu Karla Baxu a Muchovho amerického mecenáša Charlesa R. Cranea, vo vel'kej dvorane Veltržného paláca, vtedy najmodernejšej budove určenej na veltrhy (Bydžovská - Srp 2005, 242 ). ${ }^{1}$

Alfons Mucha odovzdal dielo - cyklus obrazov Slovanská epopej mestu Praha, pričom tento dar spojil s podmienkou, aby bol preň vybudovaný samostatný výstavný stánok. Túto požiadavku by sa mohlo podarit splnit v tomto Miléniu, kedže v roku 2017 Magistrát Prahy vyčlenil priestor pre stavbu galérie (priestor stanice Těšnov v Prahe). Dosial' boli obrazy inštalované najskôr na zámku Moravský Krumlov 
Dielo Alfonsa Muchu Slovanská epopej sa vyznačuje výnimočnými umeleckými kvalitami, ale zároveň je možné vnímat ho ako predľženú rukou národnooslobodzovacích snáh českého národa započatých v období raného romantizmu. Ústrednou témou sú obrazy slovanskej mytológie a českých dejín, pričom Mucha sa výberovo, a teda i subjektívne zameral na určité konkrétne a zároveň klúčové témy a udalosti. Ich obsahom je mytológia, náboženstvo a dejiny, podané v alegorickej forme. Obrazy sú venované mytológii a dejinám predovšetkým českých Slovanov, zastúpení sú tiež Srbi, Rusi, Bulhari, Chorváti, Macedónci, pobaltskí Slovania a Moravania. Slováci ako samostatný národ či kmeň nie je zmienený. Jeden obraz je venovaný téme Velkej Moravy a príchodu vierozvestcov Konštantína a Metoda na moravský Velehrad. Vedla Vierozvestcov stoja na obraze ikonické postavy svetskej vrchnosti moravské kniežatá Rastislav a Svätopluk. Na Muchových obrazoch kultúrna (mýtizovaná) pamät funguje cez topos miesta - postavy sú umiestnené a udalosti sa odohrávajú v pomerne konkrétne definovanej krajine.

Moravania $\mathrm{v}$ Muchovom poňatí sú považovaní za národ/kmeň, do ktorého zrejme autor zahrnul aj „slovenských Slovanov“. Deje sa tak v zhode s myšlienkou jednotného národa československého, resp. v tomto prípade moravsko-slovenského národa, ako sa o tom uvažovalo už od 17. storočia, ked' slovenskí evanjelici používali ako liturgický jazyk biblickú češtinu, ale tiež v súlade $s$ textom ústavy mladého štátu. ${ }^{2}$

Výjav vel'komoravských dejín, obraz príchodu Cyrila a Metoda, sa na Muchovom obraze odohráva na Velehrade na Morave, v sídle vel'komoravských kniežat. Ďalšími sídlami však boli Devín a Nitra - tieto a ani d’alšie iné miesta z územia dnešného Slovenska sa na Muchových obrazoch neobjavili, i ked’ boli českým vzdelancom známe.

Takto, ako istý paradox Muchovej východiskovej idey (t. j. vyjadrit úsilie o všeslovanskú jednotu a uplatnit obraz ako symbol vdakyvzdania na znak úcty voči novej republike, konštituovanej na pozadí súnáležitosti dvoch najbližších slovanských národov), možno interpretovat’ skutočnost', že slovenský segment dejín Velkej Moravy v Muchovom cykle nedostal priestor ${ }^{3}$.

Ideou Muchovho cyklu je pritom jednota Slovanov - všeslovanská idea. Cyklus ju nielen vyjadruje, odvolávajúc sa na spoločné korene a mytológiu, ale k nej aj vyzýva. Muchov cyklus je rovnako romantickým snom - snívaním, voči ktorému mali výhrady aj historici. V obrazoch mytológie je uplatnená umelecká imaginácia - konštrukcia a obraz dejín má mýtotvornú povahu. Do Muchovho projektu sa zapísala utopická vízia o pozitívnom vklade do dejín tohto

a od roku 2012 sú v Národnej galérii v Prahe, sídliacej vo Veltržnom paláci. Obrazy absolvovali v roku 2017 turné do Japonska, mali byt vystavené aj v Č́ne.

2 Koncom 19. storočia silnela idea spoločného jazyka Čechov a Slovákov, ked’ Ján Kollár presadzoval, aby pre slovenské etnikum bol uzákonený modifikovaný československý jazyk. Okrem iného bola dôvodom tejto vízie obava, že „maličké publikum nemuže míti literaturu“, čo možno interpretovat tak, že menšinová slovenská literatúra by nemala odbyt. Bližšie pozri: Podolan Peter, 2015, In: Zajac, 2015, 153. Pozri tiež: list Jána Kollára Aloisovi Vojtěchovi Šemberovi z 19. augusta 1845. LAPNP, fond Alois Vojtěch Šembera (Zajac, ibid., 153). Mucha mohol vychádzat tiež z Ústavy nového štátu Československa, kde sa hovorí o československom národe. Skladbu obyvatelstva predestinovala tiež otázka pri sčítaní ludu, kedy sa obyvatelia mali prihlásit k československej národnosti.

3 Muchov cyklus v rámci umeleckej licencie autora akoby „opomenul“ slovenský priestor, mytologický či historický segment národa, žijúceho na slovenskom území (územie neskoršieho Horného Uhorska). Podla niektorých historikov a teoretikov bolo pripojenie Slovenska k Česku v novej republike politicky nevyhnutným, ale prezieravým aktom, ktorý diplomaticky riešil národnostnú skladbu v novom štáte, kde nemecké obyvatel'stvo tvorilo až 20 percent (3,3 milióna). Slovensko predstavovalo nový koridor, čeliaci „nemeckému obklúčeniu“. Bližšie pozri: Jan Rychlík (Ústav českých dějin Filozofické fakulty Univerzity Karlovy), rozhovor ČT 24, Historie.cz, 4. 11. 2012. Dostupné na internete: https://ct24.ceskatelevize.cz/ archiv/1285691-narod-ceskoslovensky. 
viacnárodného „kmeňa“, ktorý by zároveň mohol zohrat úlohu aj v dalšom vývoji civilizácie. Prítomná je utopická predstava o možnom budúcom zomknutí sa Slovanov, ktorých charakterizujú čisté idey duchovnosti a nenásilia. Cyklus artikuloval, živil a rozvíjal mýtus rovnocennej alebo dokonca vedúcej úlohy Slovanov, v kontexte európskych národov (Srp 2015, 33 - 51). Neskorší vývoj, ako vieme, nepotvrdil a nenaplnil predstavy romantikov, ani tých z konca 19. storočia, ani tých z modernej doby. Ideu všeslovanského sveta sa nikdy nepodarilo uskutočnit', a tak sa nemohla ani verifikovat. Čo sa úspešne zrodilo a pomerne úspešne fungovalo bolo spolunažívanie dvoch národov v jednej republike - Československu - počas temer celého 20. storočia.

Z hladiska funkcie, ktorú by malo zohrat dielo Alfonsa Muchu - Slovanská epopej, ale aj na slovenskej strane diela napríklad Jozefa Hanulu, Martina Benku a dalších, horliace za slovanskú jednotu v akejsi pseudomytologickej forme, ktoré sa objavili vlastne až po dosiahnutí národnej a štátnej svojbytnosti oboch národov, by sme ich mali považovat za výrazový a ideový anachronizmus. ${ }^{4}$

Umeleckú a estetickú hodnotu spomínaných diel, ak ju vnímame oddelene od politiky a ideológie, tento anachronizmus neeliminoval a diela získali pretrvávajúci obdiv a úctu publika.

Zavŕšením procesu sebaurčenia národov (Čechov a Slovákov) a vznikom samostatného spoločného štátu - Československa - nezanikla potreba kontinuálneho upevňovania národného povedomia skrze figúry pamäte a mýtu (ten je možné spredmetnit' len v metaforicko-umeleckej forme) (Slavická 2015, 75 - 87). Naopak, neustálené národnostné pomery, vyplývajúce z viacnárodnej povahy Československého štátu, tieto výzvy generovali a povzbudzovali. ${ }^{5}$ Nešlo však len o samotné diela a ich obsah či ideové posolstvo, ale tiež o slávnostný ráz ich sprístupnenia a prezentácie (oslava vo verejnom priestore, napríklad vernisáž); slávnost', charakteristická istou okázalostou je tu nielen kultúrnym, ale aj politickým gestom. Pri sprístupnení Muchovho cyklu sa stala výrazom (symbolom) sebaistoty národného spoločenstva $\mathrm{v}$ podmienkach zmiešaných etník na spoločnom území.

\section{„TEMER STOROČNICA“. REINTERPRETÁCIA ROMANTICKÉHO IDEÁLU V DIELE JIŘIIHO DAVIDA. DEKONŠTRUKCIA MUCHOVHO DIELA APOTEÓZA}

Na obraz jednotného slovanského sveta reaguje temer po sto rokoch súčasný český umelec, jedna z vedúcich osobností českej postmoderny, Jiří David. Impulzom pre reakciu na Muchovo dielo u Jiř́ho Davida bola aktuálna situácia konfliktu dvoch slovanských, kedysi blízkych a vzájomne spätých národov, dnes samostatných štátov - Ruska a Ukrajiny. Apropriovaný a reinterpretovaný obraz Apoteóza Alfonsa Muchu bol základom umeleckého projektu, ktorý Jiří David realizoval na medzinárodnej prehliadke výtvarného umenia v Benátkach Biennale Contemporary Art Venezia) v roku $2015^{6}$.

4 Akoby $\mathrm{k}$ paradoxom vývinu patrí, že slovenské umenie, ktoré preferovalo národné témy, tak v monumentálnej forme, realizovanej často s dávkou mýtizácie/mytologizácie, sa neobjavilo súbežne s národnobuditelskými snahami a revolučnými výbojmi literátov (2. pol 19. stor.), ale nadobúda rozmach až s nástupom moderny (od 30-tych rokoch 20. storočia, čoho príkladom je tvorba Jozefa Hanulu (Svätí Cyril a Metod medzi ludom, 1936) či Martina Benku (Sv. Cyril a Metod, 1942), teda až v podmienkach nového štátu Čechov a Slovákov. Vtedy už boli do rozhodujúcej miery zavréšené emancipačné snahy oboch národov. Uvedené Benkovo dielo sa však týkalo už obdobia prvého slovenského štátu, kedy v spoločnosti, politike aj kultúre silneli nacionalistické tendencie.

5 Nemecké obyvatel'stvo malo v Československu, $\mathrm{v}$ dvadsiatych a tridsiatych rokoch, oproti Slovákom prevahu. Nemeckí zástupcovia sa stali súčastou československej vlády však až po roku 1926, pozri poznámku č. 2.

6 Projekt pre Bienále súčasného umenia 2015 bol postavený na spolupráci reprezentantov dvoch republík 
Jiř́ David si pre svoju maliarsku úvahu vybral posledný obraz z Muchovho cyklu - obraz Apoteóza - Slovanstvo pro lidstvo, 1926. Na Muchovom obraze dominuje ako hlavná postava a alegória Slovana - mladý silný muž spracovaný v nadrozmernej velkosti (uplatnená je tu hieratická kompozícia). V jeho pozadí mu prihliada rovnako vel'ká postava Krista. Na obraze sú dalej umiestnené postavy, reprezentujúce rôzne slovanské spoločenstvá; jednotlivé skupiny sú rozmiestnené v sofistikovanej kompozícii, prostredníctvom ktorej je vyjadrená symbolika, mytológia i historické odkazy. Mucha v tomto poslednom obraze cyklu Slovanská epopej vychádza z aktuálnej spoločensko-politickej situácie národov na rázcestí. Obraz je oslavou slovanského ducha, je plný symbolov aj živej akcie.

Jiř́ David urobil maliarsku repliku tohto obrazu v monochrómnom šedo-čierno-bielom prevedení. Nešlo však o doslovnú apropriáciu, ale o reinterpretáciu, ked’ do sémantiky Muchovho diela autor intervenoval tak, že niektoré zásadné motívy pozmenil, resp. nahradil takými, ktoré reprezentujú súčasné spoločensko-kultúrne a umelecké dianie. David zamenil niektoré motívy tak, že namiesto nich vložil do obrazu dvadsatjeden apokryfov. Takto aktivizoval jednak vnímanie diváka a jednak, v duchu postmodernej irónie, spochybnil, relativizoval a vylúčil romanticko-utopickú ideu vel'kého a spravodlivého slovanstva a dejín. Konkrétne apokryfy sa týkali niektorých postáv hrdinov, ktoré David transformoval do novodobých aktuálnych hrdinov alebo antihrdinov. David pozmenil aj niektoré figurálne symbolické motívy. Idea Slovanstva a jeho dejín dostala tak znepokojujúcu trhlinu a nepríjemnú, de-estetizujúcu pachut.

Dvadsatpät apokryfov umiestnených na Davidovej malbe komentuje a depatetizuje pohlad na dianie okolo nás. Uvedieme niekol'ko príkladov: obrazový motív kostí predstavuje pamät národa; motív pravdy alegorizuje dievča zahalené rúškom (snád' v symbolickom význame - aby sa nenainfikovalo lžami); motív Slovana nemá výzor hrdinu ako na Muchovom obraze, ale je fyzicky ochabnutý, má jazvu po apendixe, na krku má obruč (alúzia na význam slova Sláv - otrok); motív vel'kolepého oslavného venca na Muchovom obraze je zmenený na veniec z halucinogénnych húblysohlávok; motív osamelý vlk je alúziou na terorizmus; horiaci dom - symbol obete; hajlujúci Slovania (Slováci?) - odvrátená stránka pozitívneho patriotizmu a i.

Predobrazom (modelom) pre posledný nami uvedený motív apokryfu Hajlujúci Slovania bola pre maliara Jiř́ho Davida fotografia, ktorú autor zrejme vybral z databázy obrazovej galérie na internete. Fotografiu urobil reportážny fotograf Jozef Teslík v roku 1943, v čase, ked’ na Slovensku vládol klérofašistický režim a Slovensko ako samostatný štát bol v područí hitlerovského Nemecka. Teslíkova fotografia (Jozef Teslík: Oslavy 2. Celoštátneho nástupu Hlinkovej mládeže v Bratislave, r. 1943) výstižne poukazuje na gesto fašistického pozdravu na verejnom zhromaždení v Bratislave (vztýčená pravica s dlaňou nahor). Ludovost̉ a príslušnost' gesta k národu je zvýraznená odevom hajlujúcich, ktorí sú odetí v slovenskom/moravskom ludovom kroji. Fotografia ako emblematický obraz situácie bola viackrát využitá aj v súčasnej obrazovej kultúre. ${ }^{7}$ David aproprioval čast tejto fotografie, zdôrazňujúcu motív hajlovania, a volným, expresívnym maliarskym rukopisom ju včlenil ako apokryf na miesto, ktoré pôvodne na Muchovom obraze bolo bez figúr, riešené ako volný priestor, nad ktorým viali štátne zástavy. David zovšeobecnil tento Teslíkov motív a vztiahol ho na všetkých Slovanov, zrejme nechcel poukázat špeciálne na to, že len Slováci boli (aj) fašisti.

Česka a Slovenska, pričom umeleckú čast reprezentoval výtvarník Jiří David a teoretickú čast slovenská kurátorka Katarína Rusnáková. Bližšie pozri: Kapsová 2016.

7 Fotografia bola použitá napríklad na obálke publikácie pre divadelnú hru Viliama Klimáčka Holokaust. Príbeh, na ktorý by Slovensko najradšej zabudlo, Divadla Aréna Bratislava (2012), tiež pre knihu Bohunky Koklesovej $V$ tieni tretej ríše, 2010 a ako zväčšenina - artefakt na výstave Sen a skutočnost’, v Slovenskej národnej galérii v roku 2017. Fotografia je súčastou obrazovej prílohy v katalógu, resp. v obsiahlej publikácii k tejto výstave (Bajcurová - Hanáková - Koklesová 2017, 180). 
Napriek tomu ide o zaujímavú súvislost a dalo by s istou dávkou irónie povedat', že Slováci (resp. Slovensko) po sto rokoch takto ("konečne") na Muchovom (Davidom interpretovanom) obraze dostali miesto v rodine slovanských národov!

Žial', vizitka Slovákov (a Slovanov všeobecne) nie je lichotivá. Treba upozornit na drobný detail - hajlujúci Slovania majú aj moravské kroje, čo svedčí o tom, že na zhromaždenie v Bratislave prišla skupina z Moravy. Jiř́ David pri štúdiu podkladov k svojmu projektu nachádza i túto súvislost'. Do vztahu s Muchovým dielom a Davidovou kritikou sa však dostala Bratislava, ako topos udalosti spojenej s fašistickým prejavom. Davidovi však ide o zovšeobecnenie, ktoré ide hoc aj na tričko dotknutej skupiny, a hovorí, že ho viac zaujíma: „Fenomén lidovosti, folklóru (tak dodnes deklarované pravosti, ryzosti, silných tradic, atd.). Zajímal mně ve spojení s područím, pokrytectvím a pod. Zajímal mně tak i fenomén podřízenosti malých (slovanských, ale asi nejen) národů pro jejich přežití... co jsme ochotni obětovat, co raději zapomenout ve jménu svých dějin, které ani nemusí být naše... čemu jsme schopní pod nátlakem uvěřit..." (Geržová 2015, 51).

Viaceré postavy na Davidovom obraze sú zo sveta dejín umenia a ríše legiend a otvárajú další vejár asociujúcich významov: je tu portrét nemeckého konceptuálneho umelca Joseph Beuysa, srbskej performerky Mariny Abramović cválajúcej na koni; motív americkej zástavy popartového umelca Jaspera Johnsa; motív kñažky rodiacej Slovana; motív diabla, komponovaný vedla postavy Krista i Davidov autoportrét vložený do postavy škriatka.

Autor aproprioval základné tematické, kompozičné vrstvy Muchovho obrazu, iné (farba) pozmenil, prepísal v zámere dekonštruovat idealizujúco utopický obraz jednoty Slovanov. Demontáž pôvodného sa udiala v mene novej kritickej konštrukcie. Maliar pri prepise použil klasickú rukodielnu maliarsku techniku, aby mohol prechádzat procesom zrodu malby a v tomto procese mohol viest’ s Muchovým obrazom tvorivý pomyselný aj reálny dekonštruujúci dialóg8.

Pôvodný obraz Apoteosis od Alfonsa Muchu pôsobil okrem pozitívnej figurálnej symboliky, najmä výraznou farebnou symbolikou a expresiou. David deestetizoval aj túto stránku obrazu, namaloval ho v monochrómnej čierno-bielo-šedej farebnosti. Tá mohla evokovat blednúcu pamät', ale zároveň aj eliminovala farebnú symboliku. Napríklad Slovania boli na Muchovom obraze stvárnení v bielych farbách ako symbole nevinnosti. ${ }^{9}$

David posunul maliarsku reflexiu ešte d’alej. Velkorozmerný obraz ako verná čiernobiela replika s vloženými apokryfmi bola len jednou častou - segmentom inštalácie, ktorú David realizoval v Benátkach v Československom pavilóne. ${ }^{10}$ Autor umiestnil obraz v zadnej časti pavilónu tak, že diváci prichádzajúci do pavilónu vidia len vel'kú bielu plochu (zadná strana zrkadla). Oproti

8 Porovnat originál s Davidovou reinterpretáciou mohol divák vd’aka reprodukcii Muchovho obrazu na plagáte rozdávanom na výstave a uverejnený tiež v publikácii, ktorá bola súčast’ou projektu. Išlo o súbor článkov na tému globalizovanej doby, slovanstva a aktuálnych udalostí z pera významných humanitných vedcov z oblasti sociológie, filozofie, kunsthistórie (Jiří Přibáň, Katarína Rusnáková, Jacques Rancière, Karel Srp, Zygmunt Bauman, Peter Sloterdijk, Miroslav Petř́íck, Milena Slavická, Timothy Snyder, Susan Buck-Morss, Suzana Milevska, Václav Bělohradský). Publikácia zahŕňala tiež kurátorský text Kataríny Rusnákovej. Bližšie pozri Přibáň - Rusnáková (ed.), 2015; tiež Marsilio Editori (ed.), 2015, 139.

9 Slovanov a bielu farbu dával do symbolického spojenia už Ján Kollár, ked' vysvetloval symboliku Slavy dcery - kultového diela národného obrodenia (Srp 2015, 39).

10 Československý pavilón dodnes, teda aj po rozdelení Československa v roku 1993, slúži na reprezentáciu oboch krajín - Českej aj Slovenskej republiky, ktoré sa v pavilóne po dvoch rokoch striedajú. Väčšina nových štátov po rozpade pôvodných štátov (napríklad po zániku ZSSR alebo Juhoslávie) si muselo v Benátkach hladat na vystavovanie nové priestory. Napr. v ruskom, resp. v pavilóne bývalého Sovietskeho zväzu už vystavuje iba Rusko. Ukrajina a d’alšie krajiny bývalého Sovietskeho zväzu si zaobstarali či prenajali iné výstavné priestory v Benátkach. 
zrkadlu bola v pomerne malom odstupe $(1,5 \mathrm{~m})$ umiestnená mal'ba Jiř́ho Davida. Ked' chceli diváci uvidiet' obraz, museli prejst' priechodom medzi malbou a zrkadlom. Divák vnímal rôzne skreslenia a perspektívne skratky. Malý a úzky odstup vyvolával pocit stiesnenosti. Úzky priestor znemožňoval naplno uvidiet’ Davidov obraz. Súčasne mohli diváci vidiet’ v zrkadle samých seba na pozadí malby, a tak sa mohli zapojit do apokryfnej dekonštrukcie obrazových posolstiev. Mohli sa podielat' na dynamickej reinterpretácii Muchovej témy, vyvolávajúcej otázku o našej osobnej, vlastnej účasti na behu dejín. Projekt tak vdaka interaktívnej participácii návštevníkov nadobudol širšiu a aktuálnu platnost': priechod/úžina medzi obrazmi, s ohl’adom na stiesnenost', mohol pripomínat' (evokovat') koridor pre migrantov - pútnikov za lepším svetom (do novej vlasti) v časoch klimatického a vojnového ohrozenia. Davidov projekt sa na medzinárodnej prehliadke umenia stal súčastou medzinárodného dialógu o stave umenia a spoločnosti.

V časopise The Gaurdian bol ocenený ako pätnáste najlepšie dielo Bienále 2015. Po roku 1989, resp. 1993 (rok vzniku samostatných republík Slovenskej a Českej republiky), teda v novodobých dejinách prezentácie národného umenia v Československom pavilóne, to bola prvá inštalácia takého diela, v ktorom bola exponovaná úvaha o spoločensko-politickej téme. Davidovo dielo môžeme chápat ako osobitý prípad kritickej recepcie diela Alfonsu Muchu a jeho mýticko-utopickej vízie - vizuálnej ideológie všeslovanskej jednoty - myšlienky, ktorá bola blízka mysleniu učencov, vzdelancov, literátov a umelcov v období národného obrodenia.

Národné idey a kánon umenia v postmoderne podliehajú kritickému čítaniu v súlade s aktuálnymi spoločensko-politickými podmienkami a udalostami. Dekonštrukcia pôvodného však môže znamenat dvojaké vyrovnanie - môže generovat postmodernú skepsu alebo aj zárodok vízie budúceho stavu. Živá interaktívna recepcia komplexného štrukturálne viacvrstvového diela ponúkla zážitok „novej úzkosti“, ale predovšetkým výzvu k reflexii na pôdoryse medzinárodnej výstavy Benátskeho Bienále ako oslave globálneho spoločenstva.

\section{DÔVETOK - SITUÁCIA V PAVILÓNE A REÁLNA RECEPCIA AKO FYZICKO-MENTÁLNY AKT}

$\mathrm{K}$ dojmu z návštevy nášho pavilónu prispeli aj špecifické fyzické a klimatické podmienky. Počas horúceho leta 2015 bolo namáhavé strávit niekol'ko minút v československom pavilóne s presklenou strechou bez klimatizácie, v neúnosnom dusne, ked’ sa teplota blížila k 50 stupňom Celzia. Prehliadanie Davidovho obrazu i samého seba v zrkadle, v priestore úzkeho koridoru, spolu so zástupmi ludí, mohlo asociovat napríklad aj neznesitel’né a kruté podmienky migrantov putujúcich do Európy. Práve v tomto období, v horúcom lete 2015, sa denne k brehom Talianska doplavilo tisíce migrantov z Afriky a Ázie. ${ }^{11}$

\section{NA ZÁVER: INÝ (?) SVET SÚČASNOSTI}

Recepcia monumentálneho diela Alfonsa Muchu prostredníctvom interaktívnej inštalácie Jiř́ho Davida sa nesie v kritickom duchu dekonštrukcie utópie, jej premeny na distopický svet úzkosti, $\mathrm{s}$ apelom na uzretie vlastného obrazu a nášho miesta $\mathrm{v}$ súdobom svete, $\mathrm{v}$ konkrétnej situácii turbulentnej sociálnej výmeny.

11 O nemiestny aprílový žart či provokáciu sa postaral internetový, vážne sa tváriaci článok, referujúci o prezentácii tzv. islamského štátu (ISIS) na Bienále. Podla neho v Benátkach kotvila, akoby plávajúci pavilón, lod’ ISIS. Bližšie pozri: ISIS to Exhibit Floating Pavilion of Art Destruction at Venice Biennale by The Editors on April 1, 2015. Dostupné na: http://hyperallergic.com/195279/ isis-to-exhibit-floating-pavilion-of-art-destruction-at-venice-biennale/. 
Svojím spôsobom, blížiac sa k storočnici založenia Československa (2018), sa na medzinárodnom fóre (Bienále súčasného výtvarného umenia Benátky) stal mýto-distopickým obrazom nielen tohto bývalého teritória, ale širšej spoločensko kultúrnej situácie Európy.

\section{SUMMARY}

Eva Kapsová in the article focuses on the analysis of art work of famous painter Alfons Mucha Slav Epopea (1911 - 1926). Slav Epopea was important in effort of building of new state - the Czecho-Slovakia (1918). Eva Kapsová compares Mucha’s art work with postmodern artwork Apotheosis (2015) of contemporary artist Jiř́ David. Alfons Mucha dedicated his twenty-part cycle of monumental paintings to the Czech nation and donated to Prague on September 1, 1928, for the tenth anniversary of the birth of Czechoslovakia. Mucha painstakingly creates several Slavic tribes, except for the Slovaks, which can be considered a paradox, as the cycle is a tribute to the union of Czechs and Slovaks Mucha was painted Velehrad - the seat of Great Moravia, but other settlements in Slovakia - Devin or Nitra are not mentioned. Jiři David incorporated 21 apocrypha's in his reinterpretation of Mucha painting. He placed one apocrypha in a place a pictorial quotation of a documentary photograph by Jozef Teslík, from the time of the war Slovak state, which is captured by the heiling Slovaks. The Slovaks, hundred years after, were given, unfortunately, an unflattering place in the family of Slavic nations in Mucha's painting. Jiři David, in the spirit of postmodern irony, questioned, relativized and excluded the romantically utopian idea of great and righteous Slavicism.

Článok je čiastkovým výstupom z výskumu APVV-18-0257 Inkubátor multimediálnej digitálnej produkcie - recipročný transfer vedy, umenia a kreatívnych priemyslov.

\section{LITERATÚRA}

Bajcurová, Katarína - Hanáková, Petra - Koklesová, Bohunka (ed.), 2017. Sen a skutočnost. Umenie a propaganda 1939 - 1945. Bratislava: Slovenská národná galéria.

Bydžovská, Lenka - Srp, Karel (ed.), 2005: Alfons Mucha. Slovanstvo bratrské. Praha: Národná galéria.

Beňová, Katarína, 2013. Cyril a Metod vo výtvarnom umení 19. storočia na Slovensku. In: Pekarovičová, Jana - Vojtech, Miloslav (ed.): Studia Academica Slovaca. Prednášky XLIX. letnej školy slovenského jazyka a kultúry. Bratislava: Univerzita Komenského Bratislava, 39 - 59.

Beňová, Katarína - Bořutová, Dana (ed.), 2007. Osobnosti a súvislosti umenia 19. storočia na Slovensku. K problematike výskumu dejín umenia 19. storočia. Bratislava: Stimul.

Geržová, Jana, 2015. Jiří David v rozhovore s Janou Geržovou. Profil. Contemporary Art Magazine 27/2, $46-58$.

Hroch, Miroslav, 2009. Národy nejsou dílem náhody. Příčiny a předpoklady utváření moderních evropských národỉ. Praha: Sociologické nakladatelství SLON.

Kapsová, Eva, 2017. Univerzálnosṫ vizuálnej reči v medzinárodnej komunikácii. In: Hohn, Eva Poliak, Peter (ed.): Cudzie jazyky a kultúry v teórii a praxi. Foreign Languages and Cultures in Theory and Practice. Banská Bystrica: Filozofická fakulta UMB v Banskej Bystrici, 11 - 28.

Kollár, Ján, 1832. Výklad čili př́mětky a vysvětlivky ku Slávy dceře. Prague: Kníhkupectvo KOBER. Klimáček, Viliam, 2012. Holokaust. Príbeh, na ktorý by Slovensko najradšej zabudlo. Bratislava: Divadlo Aréna. 
Rusnáková, Katarína, 2015. Reflection between Poetics and Politics. In: Přibáň, Jiří - Rusnáková, Katarína (ed.) Apotheosis, Apocalypse, Apocryphon: Deifed Nations, Deified Art. Köln: Verlag der Buchhandlung Walter König, 123 - 137.

Marsilio, Editori (ed.), 2015. All the World's Futures. Venezia: Fondazione La Biennale di Venezia. Slavická, Milena, 2015. Myth and pseudomyth. In: Přibáň, Jiří - Rusnáková, Katarína (ed.) Apotheosis, Apocalypse, Apocryphon: Deifed Nations, Deified Art. Köln: Verlag der Buchhandlung Walter König, 75 - 87.

Srp, Karel, 2015. In a common dream. In: Přibáň, Jiří - Rusnáková, Katarína (ed.) Apotheosis, Apocalypse, Apocryphon: Deifed Nations, Deified Art. Köln: Verlag der Buchhandlung Walter König, $33-51$.

Steinhübel, Ján, 2004. Nitrianske kniežatstvo. Počiatky stredovekého Slovenska. Bratislava: Vydavatel'stvo RAK.

Stojanovič, Milica, 2016. Slavic mythology as a part of our life. Učenica IV razreda Vlasotince: Gimnazije "Stevan Jakovljević". http://fliphtml5.com/zjux/aoxp, 13.3.2016.

Zajac, Peter (ed.), 2016. Štúr, štúrovci, romantici, obrodenci. Bratislava: Ústav slovenskej literatúry SAV, VEDA.

Zajíček, Štefan (ed.), 2014. Svätí Cyril a Metod v umení. Zborník zo sympózia. Senica: Záhorská galéria Jána Mudrocha v Senici.

\section{KONTAKT}

prof. PhDr. Eva Kapsová, PhD.

Ústav literárnej a umeleckej komunikácie

Filozofická fakulta UKF v Nitre

Štefánikova 63

94901 Nitra

Slovenská republika

ekapsova@ukf.sk 